\title{
Furosemide Treatment, Angiotensin II, and Renal Growth and Development in the Rat
}

\author{
PASCALE H. LANE \\ Department of Pediatrics, St. Louis University School of Medicine, St. Louis, Missouri 63104
}

\begin{tabular}{|c|c|}
\hline \multicolumn{2}{|c|}{ ABSTRACT } \\
\hline $\begin{array}{l}\text { Diuretics are commonly used to treat a variety of conditions, } \\
\text { including progressive nephropathies, cardiovascular, and pulmo- } \\
\text { nary diseases. Such treatment stimulates the production of an- } \\
\text { giotensin II, an important mediator of renal growth which may } \\
\text { accelerate progressive glomerulosclerosis. To further study the } \\
\text { effects of diuretic treatment on normal renal growth and devel- } \\
\text { opment, weanling male Munich-Wistar rats received no drug, } \\
\text { enalapril, furosemide, or both drugs for } 6 \text { wk; morphometric } \\
\text { studies were then performed using standard light and electron } \\
\text { microscopic techniques. Plasma renin activity was elevated by } \\
\text { furosemide treatment. Cortical tubular growth was stimulated in } \\
\text { rats receiving furosemide or both drugs; enalapril did not affect } \\
\text { cortical tubular growth when compared with untreated animals. } \\
\text { Glomerular volume was increased in furosemide-treated animals, } \\
\text { primarily due to an increase in the proportion of mesangial cells, } \\
\text { whereas enalapril decreased glomerular volume. Furosemide also } \\
\text { increased the filtration surface area per glomerulus whereas } \\
\text { enalapril decreased it. Concurrent enalapril treatment blocked the } \\
\text { furosemide-induced changes in filtration surface area as well as } \\
\text { attenuating overall glomerular and mesangial growth. Glomeru- } \\
\text { lar changes correlated with plasma renin activity. Furosemide } \\
\text { stimulated glomerular growth, especially of mesangial cells, } \\
\text { probably via stimulation of AngII production. Given the rela- }\end{array}$ & 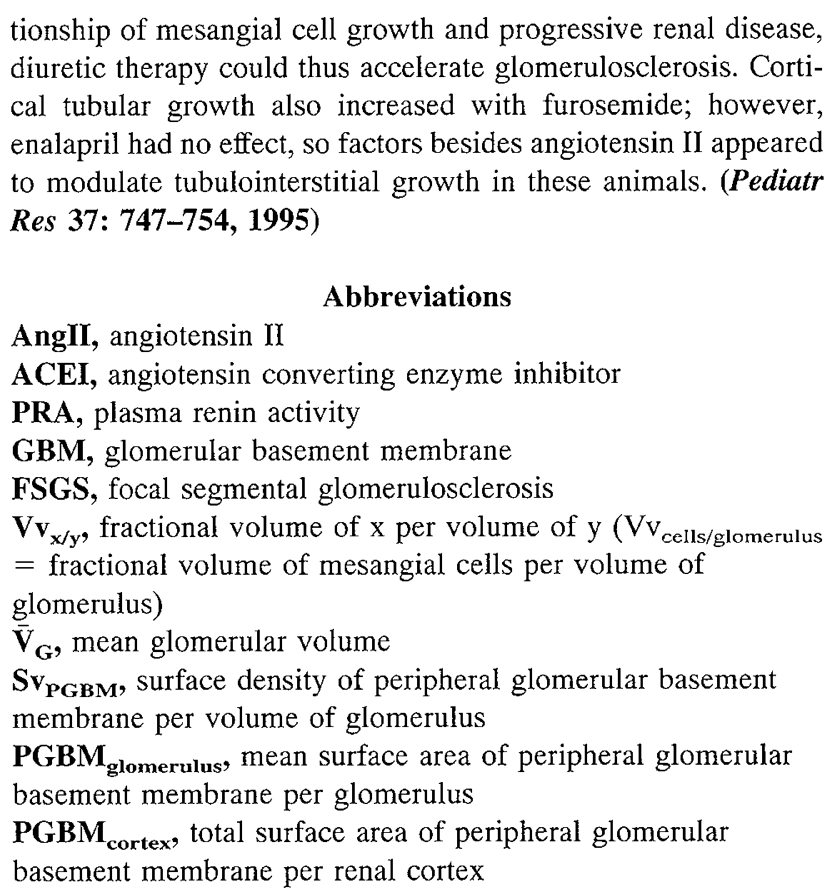 \\
\hline
\end{tabular}

The link between renal hypertrophy and progressive glomerulosclerosis has made it imperative that factors mediating renal growth, particularly mesangial cell proliferation and matrix synthesis, be identified $(1,2)$. AngII is a renal growth factor, especially in the developing kidney (3-5). All of the components of the renin-angiotensin system are active in the fetus and neonate (6-8). Studies in vitro demonstrate that AngII stimulates proliferation and hypertrophy in vascular smooth muscle, mesangial, and proximal tubular cells (9-17). Proliferation of

Received November 4, 1994; accepted February 9, 1995.

Correspondence and reprint requests: Pascale H. Lane, M.D., Division of Pediatric Nephrology, \#127A, Cardinal Glennon Children's Hospital, 1465 S. Grand Blvd., St. Louis, MO 63104.

Supported by a grant from the Fleur-de-Lis Foundation of Cardinal Glennon Children's Hospital.

Portions of this work were presented at the annual meeting of the Society for Pediatric Research/American Pediatric Society, May 2, 1994, Seattle, Washington, and were published in abstract form in Pediatric Research 35: 368A, 1994, and Journal of the American Society of Nephrology 4:442, 1993 and 5:662, 1994. mesangial cells is especially pronounced in fetal cells (16). Suppression of AngII with ACEI or the AngII receptor blocker losartan in the growing rat results in attenuation of glomerular growth independent of hemodynamic effects $(18,19)$. ACEI in adult rats does not change glomerular size, probably because there is a low rate of cellular turnover in the normal adult rat (18). ACEI or AngII receptor blockade can attenuate renal and glomerular hypertrophy associated with models of chronic renal diseases in adult animals in which cellular proliferation is increased $(20-24)$.

The effect of increased AngII on normal renal growth in vivo is unknown. Johnson et al. (25) showed that 2 wk of AngII infusion in the adult rat increased glomerular cell proliferation and induced rare areas of FSGS. Quantitative morphometry was not done, but glomeruli were otherwise described as normal (25). Miller et al. (26) found no increase in whole kidney or glomerular volume in adult rats receiving AngII infusion for 8 or $12 \mathrm{wk}$ although AngII did induce hypertension 
and FSGS. Similar studies have not been performed in growing rats.

Diuretics are commonly used to treat cardiovascular and renal syndromes which are often associated with proteinuria and progressive renal failure (27). These drugs stimulate renin secretion and AngII production, as does volume depletion of any cause (28). Furosemide may also directly stimulate renin release from the macula densa, but this effect is short-lived, lasting less than $4 \mathrm{~h}$, and would appear to play little role in the hyperreninemia produced by chronic diuretic administration (29). If AngII is an important mediator of normal and pathologic glomerular growth and sclerosis, then diuretic therapy may be capable of inducing or accelerating progressive renal disease. Furosemide treatment has been shown to accelerate cystogenesis in the diphenylthiazole model of polycystic kidney disease in the rat (24). Because sodium depletion also accelerated this model and ACEI attenuated it, activation of the renin-angiotensin system was presumed to be the mechanism for these findings (24). Clinical findings also suggest that diuretics may induce or accelerate renal disease. Walker et al found that patients with diabetic kidney disease who received a diuretic as part of their antihypertensive regimen had higher AngII levels and a faster decline in renal function over time when compared with patients who received other types of drugs (30). Diuretic treatment has also been associated with increased cardiovascular mortality in diabetic patients (31). Long-term furosemide treatment has been associated with renal insufficiency in patients with idiopathic edema; biopsy findings in these patients include glomerulosclerosis in some patients and tubular atrophy with interstitial expansion in most patients (32).

The present study was designed to examine the effect of furosemide treatment on normal renal growth and development in the rat, especially the potential role of AngII in this situation. Furosemide treatment for $6 \mathrm{wk}$ resulted in elevated PRA without systemic hypertension. Renal structure in these animals was compared with that of untreated controls, animals treated with enalapril, an ACEI, and animals receiving furosemide and enalapril to delineate the effects of furosemide treatment on normal renal growth and development.

\section{METHODS}

\section{Animals}

In a series of experiments, 50 weanling male Munich-Wistar rats, $82 \pm 4 \mathrm{~g}$ (mean $\pm \mathrm{SD}$ ), were studied. Final body weight, kidney weight, and morphometric parameters were similar for animals within each treatment group between experiments. All animals were fed a set amount of a paste made of $15 \mathrm{~g}$ of standard meal rat chow to $25 \mathrm{~mL}$ of tap water using a feeding schedule developed in pilot studies in which animals received this paste ad libitum and intake quantitated. This feeding schedule resulted in growth similar to that seen in male Munich-Wistar rats fed ad libitum chow for a similar period (18). If all animals consumed all offered food, the amount offered was then increased; if any animal failed to consume all offered food, then the amount offered was decreased for every animal until all animals did consume all offered food. Through- out these experiments, all food was consumed by all animals, so protein, calorie, and electrolyte intake were similar for all animals. The animals had free access to tap water throughout the study. Drugs were thoroughly mixed into the food paste. Ten animals received furosemide (group F), $40 \mathrm{mg} / \mathrm{d}$, as described by Warshaw (33). Thirteen animals received enalapril (group E), $2.5 \mathrm{mg} / \mathrm{d}$, an amount equivalent to that ingested by animals receiving $50 \mathrm{mg} / \mathrm{L}$ in the drinking water (Lane $\mathrm{PH}$, unpublished observations). Ten animals received both furosemide, $40 \mathrm{mg}$, and enalapril, $2.5 \mathrm{mg}$, per day (group B). The remaining 17 animals received no drug and served as controls (group C). During the final week of study tail-cuff blood pressure was determined for 19 concurrently treated animals ( 5 F, $5 \mathrm{E}, 5 \mathrm{~B}$, and $4 \mathrm{C}$ ), and 24-h urine collections were obtained for 17 animals ( $3 \mathrm{~F}, 4 \mathrm{E}, 5 \mathrm{~B}$, and $5 \mathrm{C}$ ). After 6 wk the animals underwent euthanasia in a $\mathrm{CO}_{2}$ chamber and blood was obtained. The kidneys were excised, weighed, and immersed in Karnovsky's fixative. These studies were approved by the Animal Care Committee of St. Louis University in accordance with the National Institutes of Health Guide for the Care and Use of Laboratory Animals.

\section{Biochemical Studies}

PRA was determined for $5 \mathrm{~F}$ and $5 \mathrm{C}$ animals in the laboratory of Dr. Steven Katz, Hennepin County Medical Center, Minneapolis, MN, using a modified radioimmunoassay as previously reported (34). Urine protein excretion was measured using a modification of the Lowry method (35).

\section{Morphometric Studies}

After at least $24 \mathrm{~h}$ of fixation, one kidney from all 50 animals was cut into transverse slices of $4-\mathrm{mm}$ thickness. The cut surface area of each slice was estimated by point counting with a 2-mm lattice grid. Kidney volume $\left(\mathrm{V}_{\text {kidney }}\right)$ could then be estimated with the Cavalieri principle (36). This states that the volume of an object is equal to the area of its cut surfaces multiplied by the mean section thickness. Therefore,

$$
\mathrm{V}_{\text {kidney }}=\left(\sum \mathrm{P}_{\text {kidney }} \cdot 4 \mathrm{~mm}^{2}\right) \cdot 4 \mathrm{~mm}
$$

where $P_{\text {kidney }}$ are the points falling on the kidney surface, 4 $\mathrm{mm}^{2}$ is the area per point for the grid used, and $4 \mathrm{~mm}$ is the mean section thickness.

All light and electron microscopic morphometric studies were performed by a single observer who was masked to the identity of the tissue. All 50 animals had all light and electron microscopic morphometric studies performed as described below.

Light microscopy. A single transverse section from the middle of the kidney was embedded in glycol methacrylate and sectioned at 2- $\mu \mathrm{m}$ thickness through $150-200 \mu \mathrm{m}$ of tissue for light microscopy studies. Sections were stained with Jones silver stain. Final magnification was determined by a stage micrometer. A single randomly selected section was examined at a mean magnification of 58 , and a $2-\mathrm{cm}$ lattice grid superimposed for determination by point counting of the volume fractions of medulla and cortex $\left(\mathrm{Vv}_{\text {medulla }}\right.$ and $\left.\mathrm{Vv}_{\text {cortex }}\right)$, 
the proportions of the kidney composed of medulla and cortex $\left(\mu \mathrm{m}^{3}\right.$ of medulla or cortex per $\mu \mathrm{m}^{3}$ of kidney). The volumes of cortex and medulla in each kidney (cortex $x_{\text {kidney }}$ and medulla $a_{\text {kidney }}$ ) could then be determined in the following manner:

$$
\operatorname{Cortex}_{\text {kidney }}\left(\mathrm{mm}^{3}\right)=\mathrm{Vv}_{\text {cortex } / \text { kidney }} \cdot \mathrm{V}_{\text {kidney }}\left(\mathrm{mm}^{3}\right)
$$

The same section was examined with the same grid at a mean magnification of 145 for determination of the volume fractions of glomeruli, tubules, and interstitium ( $\mathrm{Vv}_{\text {glomeruli/cortex }}$, $\mathrm{Vv}_{\text {tubules/cortex }}$, and $\left.\mathrm{Vv}_{\text {interstitium/cortex }}\right)$, the proportions of the renal cortex composed of these structures $\left(\mu \mathrm{m}^{3}\right.$ of glomeruli, tubules, or interstitium per $\mu \mathrm{m}^{3}$ of renal cortex). Interstitium was defined as that portion of the renal cortex not composed of glomeruli, tubules, arteries, arterioles, or veins at least the size of a tubule in diameter (37). Subsequent fields of cortex were examined and the points falling on glomeruli, tubules, interstitium, and total cortex were recorded until the points on cortex reached 500, approximately 28 fields at the magnification described. Previous studies of the interstitium have shown that a minimum of 12 fields are required to give reproducible results. Five hundred cortical points resulted in a similar number of points on interstitium and glomeruli, which gave reproducible results on repeated measurements. Total volumes of glomeruli (glomeruli $i_{\text {cortex }}$ ), cortical tubules (tubules cortex $_{\text {) }}$ ), and cortical interstitium (interstitium $\mathrm{cortex}_{\text {) }}$ ) could then be determined in the following manner:

$$
\text { Glomeruli }_{\text {cortex }}\left(\mathrm{mm}^{3}\right)=\mathrm{Vv}_{\text {glomeruli/cortex }} \cdot \operatorname{cortex}_{\text {kidney }}\left(\mathrm{mm}^{3}\right)
$$

In addition, at least 50 glomerular profiles from each kidney were examined for sclerosis on this section and the smallest diameter of 15 randomly selected proximal tubular profiles were measured to estimate mean proximal tubular diameter (38). Mean glomerular volume $\left(\overline{\mathrm{V}}_{\mathrm{G}}\right)$ was determined by measuring the volume of at least 15 individual glomeruli per animal using the Cavalieri principle as previously described (39).

Electron Microscopy. Several 1-mm cubes of cortex from each animal were processed for electron microscopy. The centermost glomeruli from one or more blocks were selected for thin sectioning. At least two glomeruli were studied from each animal. Sections were mounted on Formvar (Monsanto Co., St. Louis, MO)-coated slot grids, stained with uranyl acetate and lead citrate, and examined and photographed with a JEOL $100 \mathrm{~S}$ microscope as described below. A calibration standard was photographed at each microscopy session to determine final magnification.

Micrographs of an entire glomerular profile were taken and printed at a mean final magnification of 5646. These micrographs were taped together to form a montage of the entire glomerular profile. The minimal convex polygon surrounding the tuft was drawn, and a 3-cm lattice grid was superimposed on the montage to determine volume fraction of mesangium $\left(\mathrm{Vv}_{\text {mesangium/glomerulus }}\right)$, the proportion of the glomerular capillary tuft composed of mesangial cells and matrix $\left(\mu \mathrm{m}^{3}\right.$ of mesangium per $\mu \mathrm{m}^{3}$ of glomerulus) (40). At least 100 points on mesangium from two or three glomeruli were counted for each animal.

A grid with points $6 \mathrm{~cm}$ apart and two parallel $3 \mathrm{~cm}(30,000$ $\mu \mathrm{m})$ line segments associated with each point was superimposed on the glomerular montage to determine surface density of the PGBM filtration surface ( $\left.\mathrm{Sv}_{\mathrm{PGBM}}\right)$, the length of peripheral glomerular filtration surface per volume of glomerulus ( $\mu \mathrm{m}^{2}$ of surface per $\mu \mathrm{m}^{3}$ of glomerulus) (40). At least 100 intercepts from two or three glomeruli were counted for each animal. The amount of PGBM surface per glomerulus (PGBM $\left.{ }_{\text {glomerulus }}\right)$ could then be calculated as follows:

$$
\operatorname{PGBM}_{\text {glomerulus }}\left(\mathrm{mm}^{2}\right)=\operatorname{Sv}_{\mathrm{PGBM}}\left(\mu \mathrm{m}^{2} / \mu \mathrm{m}^{3}\right) \cdot \overline{\mathrm{V}}_{\mathrm{G}}\left(\times 10^{6} \mu \mathrm{m}^{3}\right)
$$

$\mathrm{Sv}_{\mathrm{PGBM}}$ was also used to determine the total PGBM surface area per kidney $\left(\mathrm{PGBM}_{\text {cortex }}\right)$ :

$$
\begin{aligned}
\operatorname{PGBM}_{\text {cortex }}\left(\times 10^{3} \mathrm{~mm}^{2}\right) \\
=\operatorname{Sv}_{\mathrm{PGBM}}\left(\mu \mathrm{m}^{2} / \mu \mathrm{m}^{3}\right) \cdot \text { glomeruli }_{\text {cortex }}\left(\mathrm{mm}^{3}\right)
\end{aligned}
$$

Multiple micrographs were taken from each glomerulus in an unbiased systematic manner and printed at a mean final magnification of 18,654. A grid with intersecting line segments $2 \mathrm{~cm}$ apart was placed over each micrograph. GBM width was determined by the orthogonal intercept method (41). At least $100 \mathrm{GBM}$ intercepts were classified from two or three glomeruli per animal. From these same micrographs, the volume fractions of mesangial cells and mesangial matrix $\left(\mathrm{VV}_{\text {cells/mesangium }}\right.$ and $\left.\mathrm{Vv}_{\text {matrix/mesangium }}\right)$ were determined from at least 100 points falling on mesangial areas. These are the proportions of the mesangium composed of mesangial cells and matrix $\left(\mu \mathrm{m}^{3}\right.$ of cells or matrix per $\mu \mathrm{m}^{3}$ of cells and matrix) (42). $\mathrm{Vv}_{\text {cells/glomerulus }}$ and $\mathrm{Vv}_{\text {matrix/glomerulus }}$, the proportions of the glomerulus composed of mesangial cells and matrix ( $\mu \mathrm{m}^{3}$ of mesangial cells or matrix per $\mu \mathrm{m}^{3}$ of glomerulus), were then calculated as follows:

$$
V v_{\text {cells/glomerulus }}=V v_{\text {cells/mesangium }} \cdot V v_{\text {menangium/glomerulus }}
$$

\section{Statistics}

All values are reported as mean $\pm \mathrm{SD}$. Values for the four groups were compared with ANOVA and Scheffé $F$ tests. $p<$ 0.05 was considered significant. Linear regression analysis was used to examine correlations between parameters. Because of the number of regression analyses performed between structural parameters and PRA, $p<0.01$ was considered significant. All computations were performed with Statview 4.01 software (Abacus Concepts, Inc., Berkeley, CA).

\section{RESULTS}

Because of small but statistically significant differences in body weight among the four groups at the onset of these experiments, the percent of initial body weight at the end of study was used to assess the effect of treatment regimens on somatic growth (Table 1). Administration of enalapril was associated with decreased weight gain over the course of the 
Table 1. Body weight and the relationship of selected parameters to body weight

\begin{tabular}{|c|c|c|c|c|}
\hline & $\begin{array}{c}\text { Control (C) } \\
(n=17)\end{array}$ & $\begin{array}{c}\text { Enalapril }(\mathrm{E}) \\
\quad(n=13)\end{array}$ & $\begin{array}{c}\text { Both drugs (B) } \\
\quad(n=10)\end{array}$ & $\begin{array}{c}\text { Furosemide (F) } \\
\quad(n=10)\end{array}$ \\
\hline Initial body weight, $\mathrm{gm}^{*}$ & $82 \pm 4$ & $85 \pm 2$ & $79 \pm 6$ & $80 \pm 4$ \\
\hline Final body weight, gm $\dagger$ & $216 \pm 20$ & $197 \pm 17$ & $181 \pm 19$ & $204 \pm 18$ \\
\hline Final weight, $\%$ of initial body weight: & $266 \pm 30$ & $232 \pm 18$ & $229 \pm 20$ & $254 \pm 16$ \\
\hline Kidney weight, gm§ & $2.22 \pm 0.33$ & $2.02 \pm 0.22$ & $2.33 \pm 0.18$ & $2.67 \pm 0.30$ \\
\hline Kidney weight per body weight, $\mathrm{m} / \mathrm{gm} \pi$ & $0.010 \pm 0.001$ & $0.010 \pm 0.001$ & $0.013 \pm 0.001$ & $0.013 \pm 0.001$ \\
\hline Cortical tubular volume per body weight, $\mathrm{mm}^{3} / \mathrm{gm}$ I & $2.07 \pm 0.31$ & $2.14 \pm 0.35$ & $3.51 \pm 0.58$ & $3.22 \pm 0.51$ \\
\hline Glomerular volume per body weight, $10^{3} \mu \mathrm{m}^{3} / \mathrm{gm} \|$ & $1.52 \pm 0.36$ & $1.29 \pm 0.25$ & $1.18 \pm 0.31$ & $2.12 \pm 0.33$ \\
\hline
\end{tabular}

All values mean \pm standard deviation. ANOVA $p<0.001$ for each parameter shown.

${ }^{*} p<0.05$ for $\mathrm{E} v s \mathrm{~B}$ or $\mathrm{F}$.

$\dagger p<0.01$ for $\mathrm{C} v s \mathrm{~B}$.

$\ddagger p<0.01$ for $\mathrm{C} v s \mathrm{E}$ and $\mathrm{C} v s \mathrm{~B}$.

$\S p<0.01$ for $\mathrm{C} v s \mathrm{~F}$ and $\mathrm{E} v s \mathrm{~F}$.

I $p<0.0001$ for $\mathrm{C} v s \mathrm{~F}$ or $\mathrm{B}$ and $\mathrm{E} v s \mathrm{~F}$ or $\mathrm{B}$.

$\| p<0.001$ for $\mathrm{F} v s \mathrm{C}, \mathrm{E}$, or $\mathrm{B}$.

study as the E and B groups weighed a smaller proportion of their baseline weight than the $\mathrm{C}$ animals (Table 1). Systolic blood pressure was not significantly altered by any of the treatment regimens, although it did tend to be lower in all of the treatment groups (C 129 \pm 28 ; E $103 \pm 8$; B $102 \pm 11$; and F $104 \pm 20 \mathrm{~mm} \mathrm{Hg}$ ). PRA was significantly elevated in $\mathrm{F}$ compared with $C$ animals $(26.0 \pm 9.4$ versus $7.8 \pm 2.3$ $\mathrm{ng} / \mathrm{mL} / \mathrm{h} ; p<0.01)$. Urine output did not differ among the four groups (C $26 \pm 2$; E $31 \pm 4$; B $38 \pm 6$; and F $36 \pm 11$ $\mathrm{mL} /$ animal/24 h), nor did urine protein excretion (C $27 \pm 2 ; \mathrm{E}$ $32 \pm 4$; B $38 \pm 6$; and F $36 \pm 10 \mathrm{mg} / \mathrm{animal} / 24 \mathrm{~h}$ ). Furosemide treatment did increase 24-h urine output when animals receiving it $(\mathrm{F}+\mathrm{B} ; 37 \pm 8 \mathrm{~mL} /$ animal $/ 24 \mathrm{~h})$ were compared with those which did not $(\mathrm{C}+\mathrm{E} ; 28 \pm 4 \mathrm{~mL} /$ animal $/ 24 \mathrm{~h} ; p<$ 0.01 ). Using these same combined groups, furosemide increased $24 \mathrm{~h}$ protein excretion $(\mathrm{F}+\mathrm{B} 37 \pm 7$ and $\mathrm{C}+\mathrm{E} 29$ $\pm 4 \mathrm{mg} / \mathrm{animal} / 24 \mathrm{~h} ; p<0.01$ ). Enalapril had no effect when groups were combined for this drug (urine output: $\mathrm{E}+\mathrm{B} 35 \pm$ 7 and $\mathrm{C}+\mathrm{F} 30 \pm 8 \mathrm{~mL} / \mathrm{animal} / 24 \mathrm{~h}$; protein excretion: $\mathrm{E}+$ B $35 \pm 6$ and C + F $30 \pm 8 \mathrm{mg} /$ animal $/ 24 \mathrm{~h}$ ).

Kidney weight and kidney weight per body weight were greater in $\mathrm{F}$ and $\mathrm{B}$ animals than in those in the $\mathrm{C}$ and $\mathrm{E}$ groups (Table 1). Kidney weight and final body weight correlated on regression analysis $(r=0.46, p<0.001)$. $\mathrm{V}_{\text {kidney }}$ was greater in the groups receiving furosemide than in the groups which did not receive this drug (C $756 \pm 132$; E $678 \pm 115$; B 1152 \pm 324 ; and $\mathrm{F} 1019 \pm 139 \mathrm{~mm}^{3} ; p<0.01$ for $\mathrm{B}$ versus $\mathrm{C}, \mathrm{B}$ versus $\mathrm{E}, \mathrm{F}$ versus $\mathrm{C}$, and $\mathrm{F}$ versus $\mathrm{E}$ by Scheffé test). Renal cortical volume was affected by furosemide administration, primarily via an increase in cortical tubular volume (Fig. 1). These differences were present even when differences in final body weight were taken into consideration (Table 1), and there were no correlations between final body weight and renal cortical volume $(r=0.01)$ or cortical tubular volume $(r=$ $0.06)$. The volumes of glomeruli and interstitium per renal cortex did not differ significantly among the groups (Fig. 1). Proximal tubular diameter was unaffected by the treatment regimens (C $43 \pm 4, \mathrm{E} 43 \pm 4, \mathrm{~F} 42 \pm 5$, and B $41 \pm 2 \mu \mathrm{m})$. Renal medullary volume did not differ among the groups (C $227 \pm 56 ; \mathrm{E} 182 \pm 57$; B $186 \pm 17$; and F $252 \pm 107 \mathrm{~mm}^{3}$ ).

$\overline{\mathrm{V}}_{\mathrm{G}}$ was significantly increased in $\mathrm{F}$ rats when compared with $\mathrm{C}, \mathrm{E}$, or $\mathrm{B}$ animals (Fig. 2). Enalapril treatment reduced $\overline{\mathrm{V}}_{\mathrm{G}}$

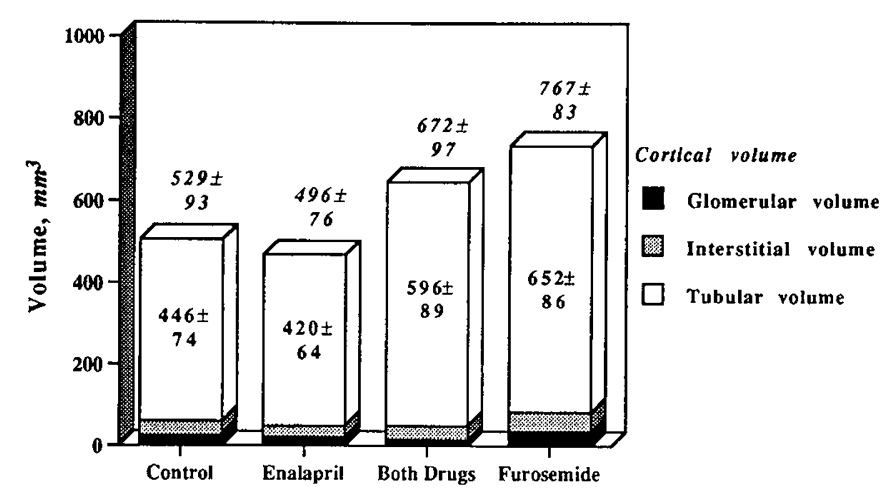

Figure 1. Total glomerular volume (solid black portion: control $25 \pm 11$; enalapril $22 \pm 7$; both drugs $15 \pm 5$; and furosemide $36 \pm 23 \mathrm{~mm}^{3}$ ), cortical interstitial volume (shaded portion: control $35 \pm 18$; enalapril $26 \pm 8$; both drugs $34 \pm 16$; and furosemide $46 \pm 21 \mathrm{~mm}^{3}$ ), cortical tubular volume (white portion, values in plain type), and total cortical volume (whole bar, values in italics) in animals receiving no drug, enalapril, both drugs, or furosemide for $6 \mathrm{wk}$ beginning at weaning. Values shown are mean $\pm \mathrm{SD}$. ANOVA $p<0.001$ for cortical tubular volume and total cortical volume; $p=$ NS for total glomerular volume and cortical interstitial volume. By Scheffé $F$ test furosemide or both drugs are greater than control or enalapril for cortical tubular volume and total cortical volume ( $p<0.01$ for each comparison).

because both $\mathrm{E}$ and $\mathrm{B}$ animals were smaller than $\mathrm{C}$ animals (Fig. 2). Retarded overall growth may have played a role in these changes, because differences between control animals and those receiving enalapril alone or with furosemide were eliminated when differences in final body weight were taken into account (Table 1), although $\overline{\mathrm{V}}_{\mathrm{G}}$ did not correlate with final body weight $(r=0.36)$ or with the percent weight gain $(r=$ 0.32). No glomerulosclerosis was noted in any animal in this study.

Glomerular ultrastructural studies revealed no differences in GBM width (C $99 \pm 11$; E $98 \pm 9$; B $105 \pm 8$; and F $101 \pm$ $15 \mathrm{~nm}) . \mathrm{Vv}_{\text {mesangium/glomerulus }}$ was significantly increased by furosemide treatment, and this increase was primarily due to an increase in $\mathrm{Vv}_{\text {cells/glomerulus }}$ (Fig. 3). These parameters were not different in $\mathrm{B}$ than in $\mathrm{C}$ animals (Fig. 3). PGBM $\mathrm{Plomerulus}$ appeared to be increased by furosemide and decreased by enalapril (C $0.075 \pm 0.020$; E $0.058 \pm 0.006$; B $0.049 \pm$ 0.018 ; and F $0.086 \pm 0.019 \mathrm{~mm}^{2} ; p<0.01$ by Scheffé test for $\mathrm{E}$ versus $\mathrm{F}$ and $\mathrm{B}$ versus $\mathrm{F} ; p<0.05$ for $\mathrm{C}$ versus $\mathrm{B}$; other 


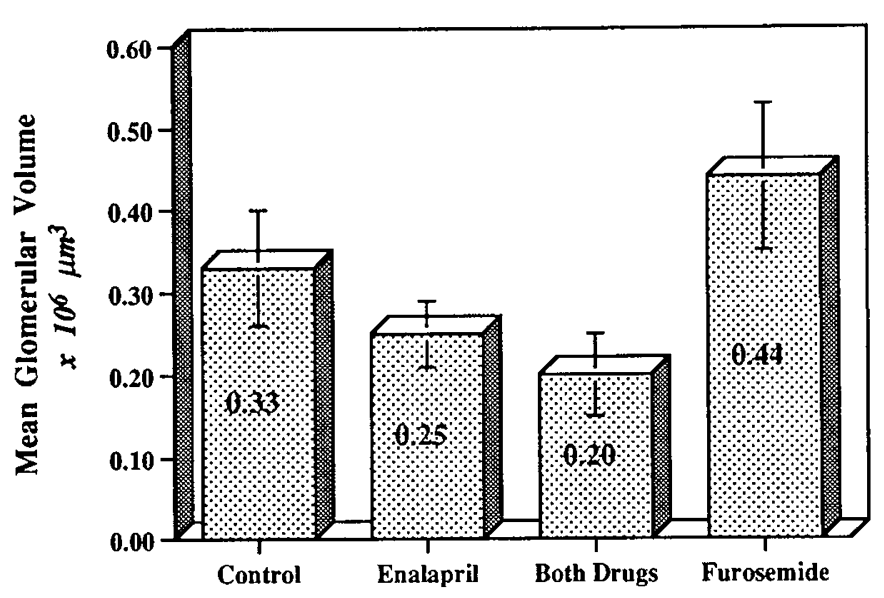

Figure 2. Mean glomerular volume in animals receiving no drug, enalapril, both drugs, or furosemide for 6 wk beginning at weaning. Values shown are mean $\pm \mathrm{SD} \times 10^{6} \mu \mathrm{m}^{3}$. ANOVA $p=0.0001$. By Scheffé $F$ test furosemide is greater than control $(p<0.01)$, enalapril $(p<0.001)$, or both drugs $(p<$ $0.001)$. Control is greater than enalapril $(p<0.05)$ or both drugs $(p<0.01)$.

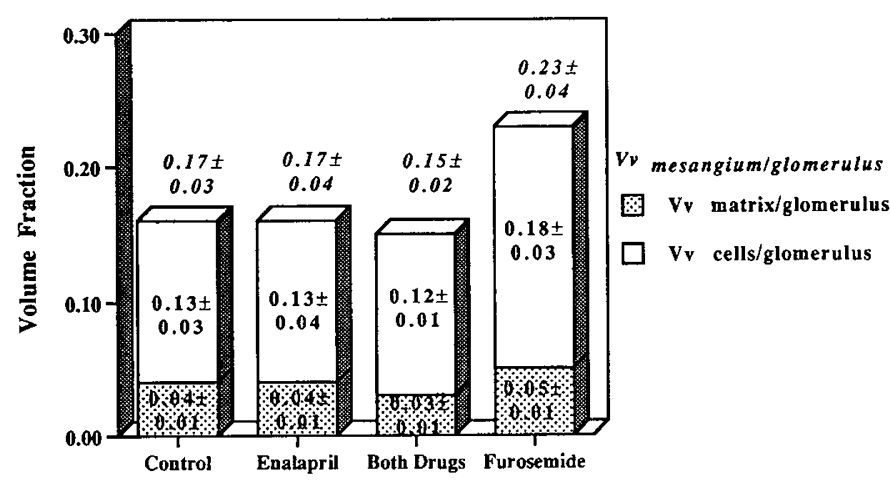

Figure 3. Volume fractions of the glomerulus composed of mesangial matrix $\left(\mathrm{Vv}_{\text {matrix/glomerulus; }}\right.$ shaded portion), mesangial cells $\left(\mathrm{Vv}_{\text {cells/glomerulus; }}\right.$ white portion), and total mesangium ( $\mathrm{Vv}_{\text {mesangium/glomerulus; }}$ whole bar) in animals receiving no drug, enalapril, both drugs, or furosemide for 6 wk beginning at weaning. Values shown are mean \pm SD. ANOVA $p<0.001$ for $\mathrm{Vv}_{\text {cells/glomerulus }}$ and $\mathrm{Vv}_{\text {mesangium/glomerulus }} ; p=\mathrm{NS}$ for $\mathrm{Vv}_{\text {matrix/glomerulus. }} \mathrm{By}$ Scheffé $F$ test furosemide is greater than control, enalapril, or both drugs for $\mathrm{Vv}_{\mathrm{m} \text { mesangium/glomerulus }}$ and $\mathrm{Vv}_{\text {cells/glomerulus }}(p<0.01$ for each comparison).

comparisons $p=\mathrm{NS})$. No significant effect on $\mathrm{PGBM}_{\text {cortex }}$ could be demonstrated (C $5.96 \pm 3.14$; E $4.97 \pm 1.40 ;$ B 3.70 $\pm 1.56 ;$ and $\mathrm{F} 7.13 \pm 4.56 \times 10^{3} \mathrm{~mm}^{2}$ ).

Regression analysis revealed many structural parameters that correlated with PRA in the five furosemide-treated animals and the five control animals in which PRA was assessed (Fig. $4)$. These included Cortex kidney $(r=0.83, p<0.01)$, Tubule$\mathrm{s}_{\text {cortex }}(r=0.82, p<0.01),(r=0.81, p<0.01$; Fig. $4 A)$, $\mathrm{Vv}_{\text {mesangium/glomerulus }}(r=0.88, p<0.001$; Fig. $4 B)$, and $\mathrm{Vv}_{\text {cells/glomerulus }}(r=0.83, p<0.01$; Fig. $4 C) . \mathrm{PGBM}_{\text {cortex }}$ showed a trend toward correlation $(r=0.74, p=0.01)$. These parameters were not additive on stepwise multiple regression analysis. The following parameters did not correlate with PRA: $\mathrm{V}_{\text {kidney }}(r=0.71), \mathrm{Vv}_{\text {cortex/kidney }}(r=0.45), \mathrm{Vv}_{\text {medulla/ }}$ kidney $(r=0.45), \mathrm{Vv}_{\text {glomeruli/cortex }}(r=0.30), \mathrm{Vv}_{\text {tubules/cortex }}$ $(r=0.18), \mathrm{Vv}_{\text {interstitium/cortex }}(r=0.30)$, medulla kidney $(r=$ $0.25)$, glomeruli cortex $(r=0.64)$, interstitium cortex $(r=0.43)$, $\operatorname{GBM}(r=0.33), \mathrm{Sv}_{\mathrm{PGBM}}(r=0.02), \mathrm{Vv}_{\text {matrix/glomerulus }}(r=$ 0.31; Fig. 4D), and PGBM glomerulus $(r=0.68)$.
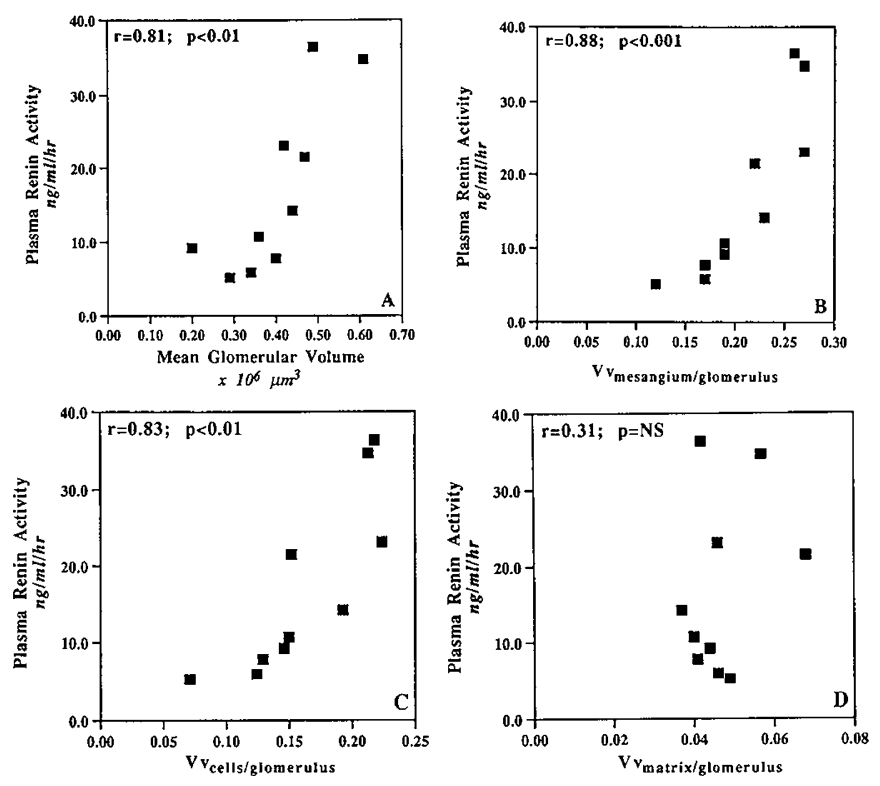

Figure 4. Correlation of glomerular structure with plasma renin activity in rats treated with furosemide or no drug for $6 \mathrm{wk}$ beginning at weaning. $A$, Mean glomerular volume; $B$, mesangial volume fraction ( $\mathrm{Vv}_{\text {mesangium/ }}$ glomerulus); $C$, mesangial cellular volume fraction $\left(\mathrm{Vv}_{\text {cells/glomerulus }}\right)$; and $D$, mesangial matrix volume fraction $\left(\mathrm{Vv}_{\text {matrix/glomerulus }}\right)$.

\section{DISCUSSION}

Six weeks of furosemide treatment during a period of growth and development resulted in renal hypertrophy in the rats described here. This hypertrophy primarily involved the renal cortex, especially the glomeruli and the cortical tubules. Glomerular hypertrophy was associated with an enlargement of the glomerular mesangium, primarily the mesangial cells. Whether this increase in mesangial cell volume represented hypertrophy, hyperplasia, or both processes cannot be ascertained from the quantitative studies performed. Glomerular changes induced by furosemide correlated with PRA and were attenuated by concurrent treatment with enalapril, suggesting that they were mediated by AngII. Cortical tubular hypertrophy induced by furosemide was not blocked by ACEI treatment, suggesting that the diuretic induced this growth via some other mechanism. Proximal tubular diameter was unaffected by any treatment regimen, suggesting that changes in the cortical tubules were in more distal portions of the nephron. As in Fogo et al.'s (18) work, ACEI attenuated normal glomerular growth. This decrease in glomerular size affected all portions of the glomerulus as there were no striking ultrastructural differences between ACEI treated and untreated animals. ACEI did not affect normal cortical tubular growth, suggesting that AngII has little effect in cortical tubular growth and development, despite the presence of AngII receptors on proximal tubule and in vitro modulation of proximal tubule cell growth by AngII (4).

AngII is an important renal growth factor in normal and pathologic renal growth (3-5). Fogo et al. first demonstrated the importance of AngII in normal glomerular growth by treating weanling rats with the ACEI enalapril for $6 \mathrm{wk}$ (18). This treatment did not result in significant lowering of systemic or glomerular blood pressures, but glomerular growth was 
attenuated in those animals who received the drug. This effect was only seen in growing animals; adult rats showed no change in glomerular volume with similar treatment (18). TufroMcReddie et al. (19) have confirmed the role of AngII in this process by treating weanling rats with the AngII receptor blocker losartan for $3 \mathrm{wk}$. This treatment resulted in lower body weight, kidney weight, and kidney weight to body weight ratios. Renal growth retardation appeared to be due to decreased cell proliferation because renal DNA content was reduced by losartan, but protein-to-DNA and RNA-to-DNA ratios were similar in treated and untreated animals (19).

ACEI or AngII receptor blockade can prevent hypertrophy associated with pathologic states in adult rats including reduced renal mass, streptozocin-induced diabetes mellitus, and diphenylthiazole-induced cystic disease (20-24). In vitro studies also provide evidence that AngII modulates glomerular cell growth. In cultured vascular smooth muscle cells AngII induces the expression of early proto-oncogenes, increases activity of growth factors, and stimulates cell hypertrophy (9-14, 17). Cultured adult human mesangial cells, which share many characteristics with vascular smooth muscle cells, show only a weak mitogenic response to AngII; however, human fetal mesangial cells show a striking proliferative response in vitro $(16,43)$. Mesangial cells may also increase collagenous and noncollagenous protein production in the presence of AngII, suggesting that, in some conditions, AngII may stimulate mesangial matrix production as well (44).

AngII may also promote proximal tubular cell growth $(4,5$, 15). AngII receptors have been identified on the brush border and basolateral membranes of proximal tubular cells, and these cells express the mRNA and protein products for all components of the renin-angiotensin system $(15,45-48)$. In a murine proximal tubular cell line AngII stimulates cell hypertrophy but not proliferation (15). AngII may enhance the proliferative effects of other growth factors on tubular cells in vitro (15). The present study suggests that AngII plays little role in normal or furosemide-induced cortical tubular growth in vivo. However, it may still play an important role in tubular growth and interstitial fibrosis during pathologic renal growth.

Few studies have examined the effect of increased AngII on renal morphology in vivo. Johnson et al. (25) infused AngII into adult rats for $14 \mathrm{~d}$ at $200 \mathrm{ng} / \mathrm{min}$, a dose that resulted in moderate hypertension. Other than rare areas of FSGS, the glomeruli of these rats were normal by light microscopy; however, quantitative morphometry was not performed. Glomerular cells showed evidence of mesangial proliferation. Small arteries demonstrated focal fibrinoid necrosis and medial hyperplasia, and mononuclear infiltrates and fibrosis were seen in the interstitium. It is possible that at least part of these changes are mediated directly by AngII; however, any or all may be due to the hypertension resulting from AngII infusion (25). Miller et al. (26) infused AngII in adult rats for 8-12 wk. Renal weight and mean glomerular volume were not increased by doses of $100 \mathrm{ng} / \mathrm{min}$ of AngII, even though systemic and glomerular pressures were significantly increased and glomerulosclerosis occurred (26). AngII thus appears to be required to induce hypertrophy in the adult animal with renal disease because ACEI treatment or AngII receptor blockade can pre- vent such growth, but AngII alone is not sufficient to stimulate renal or glomerular hypertrophy in the normal adult animal $(20-24,26)$. The response of the glomerulus to AngII may also be due to the proliferative state of the mesangial cell. Normal adult animals have relatively slow mesangial cell turnover which is increased in pathologic states (49-52).

Both studies of AngII infusion in adult animals demonstrated glomerulosclerosis whereas none was noted in the present study $(25,26)$. These differences may be due to agerelated differences, because these earlier studies dealt with adult animals whose mesangial cells probably respond differently to AngII than those of the juvenile rats in the present study. Furosemide treatment stimulates PRA without increasing systemic blood pressure; this may be why the juvenile rats did not develop glomerulosclerosis over the time period of the present study. Longer treatment might result in glomerulosclerosis in animals without hypertension. No studies of AngII infusion in juvenile rats have been performed.

Elevated AngII may not be the sole reason that furosemide treatment induces renal hypertrophy in the growing rat. The primary therapeutic use of furosemide is as a diuretic (27). This effect is achieved through competitive blockade of the $\mathrm{Na}^{+}$$\mathrm{K}^{+}-2 \mathrm{Cl}^{-}$carrier in the thick ascending limb of the loop of Henle. This results in decreased reabsorption of $\mathrm{NaCl}$ and limits the concentration gradient achieved in the medulla, further increasing water excretion (27). Furosemide also stimulates kaliuresis primarily by increased distal nephron delivery of $\mathrm{NaCl}$ with increased distal $\mathrm{Na}$ reabsorption and $\mathrm{K}$ secretion (27). Calcium and magnesium reabsorption are also inhibited, probably because their reabsorption is driven by transepithelial voltage which is eliminated by furosemide therapy (27).

Changes in distal tubules may result from changes in volume status independent of the renin-angiotensin system $(53,54)$. Rabbits fed high $\mathrm{NaCl}$ diets develop hypertrophy of distal convoluted tubule cells (53). Ellison et al. (54) studied the effects of different levels of dietary $\mathrm{NaCl}$ and furosemide infusion on renal structure and function in the adult rat. High or low sodium diets did not alter renal tubular structure or distal tubular sodium delivery, even though sodium excretion patterns changed accordingly. Chronic intraperitoneal furosemide infusion greatly increased distal tubular $\mathrm{NaCl}$ delivery and reabsorption and produced distal tubular cell hypertrophy without changes in more proximal nephron structures, presumably due to these changes in $\mathrm{NaCl}$ delivery (54). Results of the present study would support a mechanism such as this because concurrent ACEI did not block furosemide-induced tubular hypertrophy, and the proximal tubule diameter did not change, suggesting that changes in cortical tubules were restricted to more distal portions of the nephron.

Hypokalemia causes renal hypertrophy and may result from furosemide treatment (55-57). Elger et al. (57) found that in adult rats this hypertrophy primarily involves the inner stripe of the outer medulla, and glomerular tuft volume is not increased. In the study of Warshaw et al. (33), using the same diuretic regimen described here, potassium excretion was increased after the first day of treatment by furosemide, although no statistically significant differences in serum potassium levels were noted throughout the $26 \mathrm{~d}$ of their study. It thus seems 
unlikely that potassium depletion is responsible for the renal hypertrophy demonstrated in the present study, because furosemide-treated rats developed cortical hypertrophy with increased and did not develop medullary enlargement, although it is possible that this is the pattern of hypokalemic hypertrophy in juvenile animals. In the present study blood was obtained at the time of euthanasia by $\mathrm{CO}_{2}$. Although this method does not alter PRA, it does result in systemic acidosis, making potassium levels uninterpretable. Future studies will need to address blood, urine, and tissue potassium levels and control for this potentially confounding variable.

The effects of ACEI are not limited to blunting production of AngII. Angiotensin converting enzyme is identical to kininase II, the enzyme that inactivates bradykinin (58). ACEI thus decrease AngII activity and increase bradykinin activity. The latter is an important stimulus for autocrine and paracrine factors that control vasodilatation, including endotheliumderived relaxing factor and prostaglandins (58). Angiotensinconverting enzyme may play other roles as well. In vitro it is capable of acting on substance $\mathrm{P}$ and LH-releasing hormone, although no in vivo role for these activities has been defined (58). Although it seems likely that it is the anti-AngII effects of ACEI that are active in the present study, these other effects of ACEI cannot be ruled out. Further study with more specific AngII receptor blocking agents will be necessary to define the mechanism of furosemide-induced renal growth.

In summary, $6 \mathrm{wk}$ of furosemide treatment in the growing rat resulted in renal hypertrophy, particularly of the glomeruli, without glomerulosclerosis. The greatest change occurred in the cellular component of the mesangium, whether due to mesangial cell proliferation, hypertrophy, or both. Cortical tubular volume was increased by furosemide treatment as well. The glomerular changes in renal structure correlated with PRA and were blocked by concurrent treatment with enalapril, suggesting that AngII mediated glomerular and mesangial hypertrophy in this model. Other effects of furosemide treatment, such as increased distal sodium delivery or hypokalemia, may also have mediated structural changes demonstrated here, especially the tubular hypertrophy, because this latter parameter was not prevented by concurrent enalapril administration. Given the relationship of mesangial growth and glomerulosclerosis, the potential role of diuretics and AngII in progressive renal disease warrants further study.

Acknowledgments. The author acknowledges the contributions of Dr. Steven Katz who determined the PRA levels, Colleen Seamatter for her technical assistance, and the staff of the Electron Microscopy Center of St. Louis University and the staff of Comparative Medicine of St. Louis University.

\section{REFERENCES}

1. Fogo A, Ichikawa I 1989 Evidence for the central role of glomerular growth promoters in the development of sclerosis. Semin Nephrol 9:329-342

2. Striker LJ, Peten EP, Elliot SJ, Doi T, Striker GE 1991 Mesangial cell turnover: effect of heparin and peptide growth factors. Lab Invest 64:446-456

3. Ichikawa I, Harris RC 1991 Angiotensin actions in the kidney: renewed insight into the old hormone. Kidney Int 40:583-596

4. Wolf G, Neilson EG 1993 Angiotensin II as a renal growth factor. J Am Soc Nephrol 3:1531-1540
5. Wolf G, Neilson EG 1993 Angiotensin II as a hypertrophogenic cytokine for proximal tubular cells. Kidney Int 43(suppl 39):S100-S107

6. Millan MA, Carvallo P, Izumi S-I, Zemel S, Catt KJ, Aguilera G 1989 Novel sites of expression of functional angiotensin II receptors in the late gestation fetus. Science 244:1340-1342

7. Gomez RA, Cassis L, Lynch KR, Chevalier RL, Wilfong N, Carey RM, Peach MJ 1988 Fetal expression of the angiotensinogen gene. Endocrinol 123:2298-2302

8. Gomez RA, Lynch KR, Sturgill BC, Elwood JP, Chevalier RL, Carey RM, Peach MJ 1989 Distribution of renin mRNA and its protein in the developing kidney. Am J Physiol 257:F850-F858

9. Campbell-Boswell M, Robertson AL 1981 Effects of angiotensin II and vasopressin on human smooth muscle cells in vitro. Exp Mol Pathol 35:265-276

10. Berk BC, Vekshtein V, Gordon HM, Tsuda $\Upsilon 1989$ Angiotensin II-stimulated protein synthesis in cultured vascular smooth muscle cells. Hypertension 13:305-314

11. Geisterfer AAT, Peach MJ, Owens GK 1988 Angiotensin II induces hypertrophy, not hyperplasia, of cultured rat aortic smooth muscle cells. Circ Res 62:749-756

12. Naftilan AJ, Pratt RE, Dzau VJ 1989 Induction of platelet-derived growth factor A-chain and c-myc gene expressions by angiotensin II in cultured rat vascular smooth muscle cells. J Clin Invest 83:1419-1424

13. Taubman MB, Berk BC, Izumo S, Tsuda T, Alexander RW, Nadal-Ginard B 1989 Angiotensin II induces c-fos mRNA in aortic smooth muscle. J Biol Chem 264:526530

14. Naftilan AJ, Gilliland GK, Eldridge CS, Kraft AS 1990 Induction of the protooncogene c-jun by angiotensin II. Mol Cell Biol 10:5536-5540

15. Wolf G, Neilson EG 1990 Angiotensin II induces cellular hypertrophy in cultured murine proximal tubular cells. Am J Physiol 259:F768-F777

16. Ray PE, Aguilera G, Kopp JB, Horikoshi S, Klotman PE 1991 Angiotensin II receptor-mediated proliferation of cultured human fetal mesangial cells. Kidney Int 40:764-771

17. Itoh H, Mukoyama M, Pratt RE, Gibbons GH, Dzau VJ 1993 Multiple autocrine growth factors modulate vascular smooth muscle cell growth response to angiotensin II. J Clin Invest 91:2268-2274

18. Fogo A, Yoshida Y, Yared A, Ichikawa I 1990 Importance of angiogenic action of angiotensin II in the glomerular growth of maturing kidneys. Kidney Int 38:10681074

19. Tufro-McReddie A, Johns DW, Geary KM, Dagli H, Everett AD, Chevalier RL, Carey RM, Gomez RA 1994 Angiotensin II type 1 receptor: Role in renal growth and gene expression during normal development. Am J Physiol 266:F911-F918

20. Anderson S, Meyer TW, Rennke HG, Brenner BM 1985 Control of glomerular hypertension limits glomerular injury in rats with reduced renal mass. J Clin Invest 76:612-619

21. Lafayette RA, Mayer G, Park SK, Meyer TW 1992 Angiotensin II receptor blockade limits glomerular injury in rats with reduced renal mass. J Clin Invest 90:766-771

22. Zatz R, Dunn BR, Meyer TW, Anderson S, Rennke HG, Brenner BM 1986 Prevention of diabetic glomerulopathy by pharmacological amelioration of glomerular capillary hypertension. J Clin Invest 77:1925-1930

23. Anderson S, Rennke HG, Garcia DL, Brenner BM 1989 Short and long term effects of antihypertensive therapy in the diabetic rat. Kidney Int 36:526-536

24. Torres VE, Berndt TJ, Okamura M, Nesbit JW, Holley KE, Carone FA, Knox FG, Romero JC 1988 Mechanisms affecting the development of renal cystic disease induced by diphenylthiazole. Kidney Int 33:1130-1139

25. Johnson RJ, Alpers CE, Yoshimura A, Lombardi D, Pritzl P, Floege J, Schwartz SM 1992 Renal injury from angiotensin II-mediated hypertension. Hypertension 19:464474

26. Miller PL, Rennke HG, Meyer TW 1991 Glomerular hypertrophy accelerates hypertensive glomerular injury in rats. Am J Physiol 261:F459-F465

27. Wittner M, Di Stefano A, Wangemann P, Greger R 1991 How do loop diuretics act? Drugs 41(suppl 3):1-13

28. Rose BD 1989 Clinical use of diuretics. In: Clinical Physiology of Acid-Base and Electrolyte Disorders. McGraw-Hill, New York, pp 389-415

29. Francis GS, Siegel RM, Goldsmith SR, Olivari MT, Levine TB, Cohn JN 1985 Acute vasoconstrictor response to intravenous furosemide in patients with chronic congestive heart failure. Ann Intern Med 103:1-6

30. Walker WG, Hermann J, Yin D-P, Murphy RP, Patz A 1987 Diuretics accelerate diabetic nephropathy in hypertensive insulin-dependent and non-insulin-dependent subjects. Trans Assoc Am Phys 100:305-315

31. Warram JH, Laffel LMB, Valsania P, Christlieb AR, Krolewski AS 1991 Excess mortality associated with diuretic therapy in diabetes mellitus. Arch Intern Med 151:1350-1356

32. Shichiri M, Shiigai T, Takeuchi J 1984 Long-term furosemide treatment in idiopathic edema. Arch Intern Med 144:2161-2164

33. Warshaw BL, Anand SK, Kerian A, Lieberman E 1980 The effect of chronic furosemide administration on urinary calcium excretion and calcium balance in growing rats. Pediatr Res 14:1118-1121

34. Trostel KA, Katz SA, Osborn JW 1991 Functional evidence for sympathetic nerve activity in conscious cervical spinal rats. Am J Physiol 261:R434-R441

35. Ohnishi S, Barr J 1978 A simplified method of quantitating proteins using the biuret and phenol reagents. Anal Biochem 86:193-200

36. Gundersen H, Jensen E 1987 The efficiency of systematic sampling in stereology and its prediction. J Microsc 147:229-263

37. Lane PH, Steffes MW, Fioretto P, Mauer SM 1993 Renal interstitial expansion in insulin-dependent diabetes mellitus. Kidney Int 43:661-667

38. Moskowitz DW, Schneider AN, Lane PH, Schmitz PG, Gillespie KN 1992 Effect of epidermal growth factor in the rat $5 / 6$ renal ablation model. J Am Soc Nephrol 3:1113-1118 
39. Lane PH, Steffes MW, Mauer SM 1992 Estimation of glomerular volume: A comparison of four methods. Kidney Int 41:1085-1089

40. Ellis EN, Steffes MW, Goetz FC, Sutherland DER, Mauer SM 1986 Glomerular filtration surface in type I diabetes mellitus. Kidney Int 29:889-894

41. Jensen E, Gundersen H, Østerby R 1979 Determination of membrane thickness distribution from orthogonal intercepts. J Microsc 115:19-33

42. Steffes MW, Bilous RW, Sutherland DE, Mauer SM 1992 Cell and matrix components of the glomerular mesangium in type I diabetes. Diabetes 41:679-684

43. Schlondorff D 1987 The glomerular mesangial cell: an expanding role for a specialized pericyte. FASEB J 1:272-281

44. Homma T, Hoover R, Ichikawa I, Harris R 1990 Angiotensin II induces hypertrophy and stimulates collagen production in cultured rat glomerular mesangial cells. Clin Res 38:358

45. Kugler P, Wolf G, Scherberich J 1985 Histochemical demonstration of peptidases in the human kidney. Histochemistry 83:337-341

46. Marchetti J, Roseau S, Alhenc-Gelas F 1987 Angiotensin I converting enzyme and kinin-hydrolyzing enzymes along the rabbit nephron. Kidney Int 31:744-751

47. Yanagawa N, Capparelli AW, Jo Od, Friedal A, Barrett JD, Eggena P 1991 Production of angiotensinogen and renin-like activity by rabbit proximal tubular cells in culture. Kidney Int 39:938-941

48. Edwards RM, Aiyar N 1993 Angiotensin II receptor subtypes in the kidney. J Am Soc Nephrol 3:1643-1652

49. Pabst R, Sterzel RB 1983 Cell renewal of glomerular cell types in normal rats. An autoradiographic analysis. Kidney Int 24:626-631
50. Bradfield JW, Cattell V 1977 The mesangial cell in glomerulonephritis I. Mechanisms of hypercellularity in experimental immune complex glomerulonephritis. Lab Invest 36:481-486

51. Bradfield JW, Cattell V, Smith J 1977 The mesangial cell in glomerulonephritis II. Mesangial proliferation caused by Habu snake venom in the rat. Lab Invest 36:487492

52. Pesce C, Striker L, Peten E, Elliot S, Striker G 1990 Persistence of proliferation in late glomerulosclerotic lesions in mice transgenic for bovine growth hormone (bGH). J Am Soc Nephrol 1:639

53. Kaissling B, Bachmann S, Kriz W 1985 Structural adaptation of the distal convoluted tubule to prolonged furosemide treatment. Am J Physiol 248:F374-F381

54. Ellison DH, Velázquez H, Wright FS 1989 Adaptation of the distal convoluted tubule of the rat: Structural and functional effects of dietary salt intake and chronic diuretic infusion. J Clin Invest 83:113-126

55. Oliver J, MacDowell M, Welt L, Holliday M, Hollander W, Winters R, Williams T, Segar W 1957 The renal lesions of electrolyte imbalance. J Exp Med 106:563-574

56. Toback FG, Ordónez NG, Bortz SL, Spargo BH 1976 Zonal changes in renal structure and phospholipid metabolism in potassium-deficient rats. Lab Invest 34:115-124

57. Elger M, Bankir L, Kriz W 1992 Morphometric analysis of kidney hypertrophy in rats after chronic potassium depletion. Am J Physiol 262:F656-F667

58. Costerousse O, Jaspard E, Wei L, Corvol P, Alhenc-Gelas F 1992 The angiotensin I-converting enzyme (kininase II): molecular organization and regulation of its expression in humans. J Cardiovasc Pharmacol 20(suppl 9):S10-S15 